\title{
FAKTOR SOSIAL DENGAN SELF ESTEEM (HARGA DIRI) PADA REMAJA DIPANTI ASUHAN
}

\author{
Anisa Febristi ${ }^{1}$, Yulastri Arif'2, Reni Dayati ${ }^{3}$ \\ ${ }^{1}$ Mahasiswa Universitas Andalas \\ Email : anisafebristifdk@yahoo.com \\ 2 Dosen Fakultas Keperawatan universitas Andalas \\ Email : yulastriarif@nrs.unand.ac.id \\ ${ }^{3}$ Dosen Fakultas Keperawatan universitas Andalas \\ Email : renidayati72@gmail.com
}

\begin{abstract}
Background: Self-esteem is an evaluation of an individual compared to the achievement of an individual's ideal. The self-esteem formation of adolescent orphanages begins individuals, caregivers, parents, peers, social and the environment that will affect individual self-esteem.

Purpose: This study aims to determine the relationship between social factors and Self Esteem in Adolescents Who Live in Orphanages.

Method: Descriptive analytic research design, cross-sectional study approach. The research location was 30 orphanages in the city of Padang. Samples of 256 teens with proportional stratified random sampling technique. Data were analyzed using chi-square and logistic regression analysis.

Result: The results of the study were more than half (52.3\%) of adolescents in the orphanage experienced low Self Esteem. From the research that has been done, it is known that there is no significant relationship between social factors and values with $p$ Value $<\alpha(P=0.504)$.

Conclusion: It is expected that with the results of this study, the orphanage staff can improve the preventive and promotive symptoms of Self Esteem in adolescents from other factors such as individual factors, caregivers, parents and the environment at the orphanage.
\end{abstract}

Keyword : Self Esteem, Social factors related to Self Esteem, Youth

\section{ABSTRAK}

Latar Belakang: Harga diri merupakan sebuah penilaian yang dilakukan terhadap diri individu dibandingkan dengan pencapaian ideal diri individu. Pembentukan harga diri remaja panti asuhan dimulai individu, pengasuh, orang tua, teman sebaya, sosial dan lingkungan yang akan mempengaruhi harga diri individu.

Tujuan: Penelitian ini bertujuan untuk mengetahui hubungan antara faktor sosial dengan Self Esteem (Harga Diri) Pada Remaja Yang Tinggal Dipanti Asuhan.

Metode: Desain penelitian deskriptif analitik, pendekatan cross secsional study. Lokasi penelitian adalah 30 Panti Asuhan dikota Padang.Sampel 256 remaja dengan teknik proportional stratified random sampling. Data dianalisis menggunakan chi square dan analisis regresi logistik.

Hasil Penelitian: Hasil penelitian adalah lebih dari setengah $(52,3 \%)$ remaja di panti asuhan menagalami Self Esteem yang rendah. Dari hasil penelitian yang telah dilakukan diketahui tidak ada hubungan yang bermakna antara faktor Sosial dengan nilai dengan pvalue $<\alpha(P=0,504)$.

Kesimpulan: Diharapkan dengan hasil penelitian ini petugas panti dapat meningkatkan preventif dan promotif tentang gejala Self Esteem pada remaja dari faktor lainnya seperti faktor individu, pengasuh, orangtua maupun lingkungan dipanti asuhan.

Kata Kunci: Self Esteem (harga diri), faktor sosial yang berhubungan dengan Self Esteem (Harga Diri), Remaja.

\section{PENDAHULUAN}

Remaja merupakan masa transisi dari masa kanak-kanak menuju masa dewasa. Batas usia remaja yaitu 10-20 tahun dengan pembagian remaja awal 10-14 tahun, remaja akhir 15-20 tahun (WHO, 2015). Masa kritis remaja berada dalam 
periode fisik, sosial, psikologis, kognitif serta kemampuan untuk mengekspresikan dan memahami emosi untuk memberikan pengalaman emosional yang mempengaruhi perilaku (Parasar \& Dewangan, 2018). Masa remaja akan menimbulkan perubahan-perubahan fisik yang membentuk konsep dirinya dan menilai kebermaknaan dirinya dalam kehidupan (Nurliana, 2017)

Menurut World Health Organization (2017) remaja di dunia berjumlah $8 \%$ dari populasi dunia (1,2 juta jiwa berusia 10 sampai 19 tahun). mencatat bahwa jumlah remaja dengan gradasi umur 15-20 tahun di Indonesia berjumlah 22.233.393 jiwa dengan 2,5\% remaja tinggal di panti asuhan. Dengan demikian dapat diperkirakan jumlah remaja di panti asuhan akan terus meningkat (Badan Pusat Statistik, 2018).

Salah satu hal yang perlu untuk diperhatikan dalam peningkatan remaja adalah permasalahan psikologis pada remaja panti. Permasalahan psikologis remaja yang diasuh di panti asuhan dikarenakan remaja tidak menemukan lingkungan yang sama dengan di rumahnya dan sosok orang tua. Remaja cenderung mengubah kepribadian menjadi inferior, pasif, apatis, menarik diri, mudah putus asa, penuh dengan ketakutan dan kecemasan, sehingga remaja akan sulit menjalin hubungan sosial dengan orang lain (Martin, 2015). Penelitian yang dilakukan oleh Parasar \& Dewangan (2018) pada remaja yang berusia 12 sampai 18 tahun didapatkan bahwa remaja yang tinggal di panti asuhan mengalami rata-rata tingkat depresi 10,3 lebih tinggi dan 2,02 lebih rendah pada aspek harga diri dibandingkan remaja yang memiliki orang tua. Remaja di panti asuhan sangat rentan untuk mengalami gangguan kesehatan mental.

Permasalahan kesehatan jiwa bagi remaja menjadi salah satu perhatian dunia saat ini. Menurut WHO (2018) masa remaja merupakan salah satu tahap perkembangan yang paling berisiko dalam kesehatan jiwa. Permasalahan kesehatan jiwa merupakan penyebab ketiga terbesar pada kematian remaja. Salah satu faktor penyebab permasalahan kesehatan jiwa pada remaja adalah rasa harga diri yang rendah. Bista, Thapa, Sapkota, Singh, dan Pokharel (2016) mengatakan bahwa permasalahan kesehatan jiwa remaja disebabkan oleh kurangnya perhatian dari lingkungan sekitar remaja, baik itu saat berada di sekolah maupun sewaktu bersama keluarga di rumah. Dengan demikian, terlihat bahwa perkembangan remaja memiliki kerentanan yang tinggi untuk memiliki permasalahan kesehatan jiwa.

Kesehatan jiwa pada remaja tergantung pada tahap perkembangan yang dilaluinya. Menurut
Erikson (2012) tahap perkembangan remaja meliputi identitas vs kekacauan identitas. Remaja akan mencari jati dirinya tidak hanya dilingkungan keluarga, sekolah namun juga dilingkungan masyarakat. Dalam pencarian identitas ini akan menggambarkan konsep diri pada remaja tersebut. Konsep diri merupakan ciri khas bagi seorang individu. Konsep diri merupakan suatu persepsi dari seorang individu yang kompleks dan interaktif yang membuat individu tersebut percaya terhadap kehidupan dan kebiasaannya yang sesuai dengan kultur atau budaya (Kraja, 2014). Konsep diri adalah hasil penilaian seseorang terhadap kepribadian yang dimilikinya dan menjadi pembeda dengan individu lainnya yang dibentuk secara primer dan sekunder (Bharathi \& Sreedevi, 2013). Konsep diri yang tidak bagus akan menimbulkan harga diri rendah pada remaja.

Harga diri pada remaja adalah salah satu hal yang penting dalam perkembangannya. Harga diri merupakan sebuah penilaian yang dilakukan terhadap diri individu dibandingkan dengan pencapaian ideal diri yang telah ditetapkan sebelumnya. Harga diri dapat berasal dari diri sendiri atau dari orang lain, misalnya dalam bentuk pengakuan(Stuart, 2012). Harga diri tidak dapat dipindahkan antara individu yang satu kepada individu yang lain dan tidak dapat diberikan kepada orang lain (Schemmel, 2018). Menurut Muhith (2015) didapatkan bahwa permasalahan pada kesehatan fisik cenderung menyebabkan individu mengalami harga diri rendah.

Pembentukan harga diri remaja panti asuhan dimulai teman sebaya dan lingkungan. Kebiasaan ikut-ikutan serta ingin menjadi seperti teman bahkan orang di lingkungan tersebut akan mempengaruhi harga diri individu (Preckel, Niepel, Schneider, \& Brunner, 2013). Lingkungan yang ramah terhadap individu dapat membuat harga diri yang baik terhadap seorang remaja. Sementara itu jika seorang remaja berada di lingkungan yang selalu meremehkan atau keras, cenderung remaja akan takut dan mempengaruhi harga dirinya (Webb \& Mccormick, 2014). Bukan hanya lingkungan, namun orang tua juga menjadi salah satu faktor yang dapat mempengaruhi harga diri seorang remaja.

Pembentukan harga diri juga dipengaruhi oleh faktor sosial yaitu teman sebaya dan lingkungan. teman dapat membentuk kepribadian, kebiasaan bahkan identitas diri individu. Kebiasaan ikut-ikutan serta ingin menjadi seperti teman bahkan orang di lingkungan tersebut akan menentukan harga diri individu (Preckel et al., 2013). Sementara 
itu, faktor orang terdekat apalagi orang tua juga dapat mempengaruhi harga diri seorang individu.

Panti asuhan merupakan salah satu Lembaga Kesejahteraan Sosial Anak. Indonesia memiliki standar pengasuhan untuk Lembaga Kesejahteraan Sosial Anak yang tertulis dalam Peraturan Menteri Sosial No 30 tahun 2011. Dalam Peraturan tersebut menyatakan bahwa peran dari sebuah Lembaga Kesejahteran Sosial Anak adalah memberikan pelayanan bagi anak yang membutuhkan pengasuhan alternatif. Jika anak tidak mendapatkan pengasuhan dari keluarga, kerabat, atau keluarga pengganti, maka alternatif terakhir adalah pengauhan berbasis Lembaga Kesejahteraan Sosial Anak. Pelayanan tersebut beperan sebagai pengganti orang tua (Abdallat, 2012). Hal ini berarti bahwa lembaga tersebut bertanggung jawab untuk memenuhi hak-hak anak.

Hak anak remaja yang dimaksud adalah anak mendapat perhatian dalam hal perkembangan secara psikologis maupun fisik. Hak seorang anak remaja dapat berupa hak secara fisik dan hak secara psikologis. Idealnya seorang pengasuh mengasuh lima orang anak (Peraturan Menteri Sosial, 2011). Pengasuh berperan untuk mengurus, memberikan perawatan, perhatian, dukungan dan kasih sayang. Remaja akan dapat berhubungan baik dengan lingkungan apabila pengasuh panti dapat memberikan kesempatan dan bimbingan serta kasih sayang yang cukup (Bettmann, Mortensen, \& Akuoko, 2015). Pengasuh memiliki peran yang penting dalam memenuhi hak seorang anak remaja dipanti asuhan. Dengan demikian pengasuh tidak hanya bekerja dalam mengasuh anak panti, tetapi juga membantu anak memenuhi tugas perkembangan dengan memberikan beberapa kesempatan pada anak.

Kesempatan yang diberikan oleh pengasuh bagi anak untuk membina hubungan dengan orang banyak bertujuan agar remaja dapat merasakan bahwa dirinya diakui, diterima dan dihargai di lingkungan masyarakat. Menurut Llapo (2015) perhatian, bimbingan, dukungan, dan kasih sayang yang tidak bisa tercurahkan pada satu anak saja, sangat memungkinkan bahwa anak akan merasa kurang mendapatkan perhatian, dukungan dan kasih sayang dimana $56 \%$ remaja yang tinggal di panti asuhan menutup diri dan mengalami permasalahan psikologis yang berujung pada harga diri rendah pada remaja tersebut.

Menurut Gürsoy et al(2012) remaja yang tinggal di panti akan memiliki konsep diri yang negatif dan akan mengakibatkan harga diri rendah karena faktor lingkungan sosial. Lingkungan sosial akan membuat remaja menjadi mengurung diri dan tidak berani berbaur dengan masyarakat dan teman sebaya. Remaja akan menjadi tidak percaya diri dan merasa malu dengan keadaannya. Hal ini juga akan mengganggu perkembangannya.

Badan Pusat Statistik (2018) mencatat bahwa remaja dengan gradasi umur 15-20 tahun di Sumatera Barat berjumlah 3,4 juta jiwa. Berdasarkan hasil penelitian yang dilakukan oleh Syawaluddin (2015)dapat diketahui bahwa remaja panti asuhan di Kota Padang yang mengalami gangguan konsep diri adalah $56,9 \%$ perempuan dan $63,5 \%$ laki-laki. Berdasarkan data ini dapat disimpulkan bahwa lebih dari separuh remaja panti asuhan di Kota Padang mengalami gangguan konsep diri. Badan Pusat Statistik (2017) mencatat jumlah panti asuhan di Kota Padang adalah 30 unit. Sedangkan jumlah anak yang diasuh di panti asuhan sebanyak 1.292 anak asuh dengan usia yang bervariasi. Variasi anak asuh yang berada di Kota Padang berkisar antara umur 5 tahun sampai 24 tahun. Sedangkan yang usia remaja berjumlah 855 orang dan jumlah remaja yang memiliki orang tua sebanyak 768 orang anak asuh.

Berdasarkan studi pendahuluan yang peneliti lakukan pada tanggal 20 sampai 25 September 2018 dibeberapa panti asuhan di dapatkan bahwa dari 15 orang remaja panti asuhan Yayasan Darul Ma'arif Al Karimiyah 12 orang (80 $\%$ ) diantaranya mengatakan bahwa mereka merasa malu, minder untuk pulang kampung karena tinggal di panti asuhan dan merasa tidak sama dengan teman sebayanya disekolah maupun lingkungan baik dalam hal penampilan, ekonomi maupun prestasi.3 orang $(20 \%)$ lainnya sering diejek temantemannya dengan sebutan "anak panti". Berdasarkan wawancara dengan 15 orang anak $(100 \%)$, semuanya mengatakan bahwa mereka merasa sedih karena sangat ingin seperti anak lainnya yang bisa bertemu dengan orang tuanya.

Hasil wawancara peneliti dengan 3 orang pengurus panti asuhan Yayasan Darul Ma'arif Al Karimiyah didapatkan bahwa kebanyakan anak asuh yang berada di panti asuhan terdiri dari anak yatim yang memang diantarkan oleh pihak kerabat disaat mereka berumur dibawah 5 tahun. Banyak juga anak asuh yang hanya di tinggal digerbang panti oleh orang tuanya, hal ini karena permasalah ekonomi atau masalah perceraian. Awal mereka tinggal di panti, kebanyakan dari mereka mengurung diri di kamar karena tidak terbiasanya berada di lingkungan Panti.Bahkan ada anak asuh yang sudah berumur 15 tahun yang pendiam karena faktor ejekan dan hinaan dari teman-teman disekolahnya. Selain itu 3 dari 10 pengasuh mengatakan tidak dapat memberikan perhatian 
penuh kepada anak asuh dikarenakan tidak memungkinkan untuk mengelola semua anak. Hal ini terjadi karenakan jumlah yang banyak, diperberat dengan ada beberapa pengasuh yang izin.

Pengasuh panti asuhan Yayasan Darul Ma'arif Al Karimiyah juga mengatakan bahwa anak asuh memiliki hubungan yang baik antar mereka didalam panti, namun mereka merasa minder dengan teman sebaya jika berada disekolah. Remaja yang tinggal di panti asuhan ini sebanya $60 \%$ jarang dikunjungi orang tua mereka dengan alasan perekonomian. Sedangkan untuk pulang kampung anak asuh juga tidak mau untuk pulang karna malu. Selain itu, belum pernah ada petugas kesehatan atau puskesmas yang datang untuk memberikan penyuluhan kesehatan, termasuk kesehatan mental.

Hal serupa juga diungkapkan oleh pengasuh dari Panti Asuhan Al-Hidayah dari 15 orang anak,13 anak (86,6\%) diantaranya mengatakan bahwa merasa dirinya sering dikasihani oleh lingkungan sekitar karena tinggal di panti asuhan dan 2 anak (13,3\%) lainya mengalami ketidaknyamanan, merasa malu, dan minder saat menjalin hubungan dengan orang yang berada diluar panti maupun disekolah dan selain itu, remaja panti jika memiliki masalah cenderung menyimpan masalahnya sendiri dibandingkan untuk bercerita dengan orang lain maupun kepada penagasuh. Berdasarkan latar belakang tersebut, peneliti tertarik melakukan penelitian mengenai Hubungan Faktor Sosial Dengan Self Esteem (Harga Diri) Pada Remaja Dipanti Asuhan Di Kota Padang

\section{METODE PENELITIAN}

Jenis penelitian yang digunakan adalah penelitian deskriptif analitik dengan pendekatan cross sectional study dimana peneliti akan melakukan pengukuran variabel independen dan dependen, kemudian menganalisis data untuk mencari hubungan antar variabe. Data primer dan sekunder dikumpulkan dengan teknik pengumpulan data yang dilakukan melalui angket (kuesioner) dari Rossenberg Self-Esteem Scale (RSES) untuk melihat harga diri yang ada pada remaja, kuisioner Tennessee Self Concept Scale (TSCS) untuk melihat faktor sosial, pengasuh, orang tua dan individu yang memberikan pengaruh pada individu remaja. Penelitian ini dilakukan pada 30 unit panti asuhan di kota Padang mulai dari bulan september $2018 \mathrm{~s} / \mathrm{d}$ februari 2019. Populasi pada penelitian ini adalah remaja yang tinggal dipanti asuhan yang berumur 15 tahun sampai 20 tahun yaitu sebanyak 768. Peneliti menggunakan porposional random sampling sehingga didapatkan jumlah sampel sebanyak 254 remaja.

\section{HASIL DAN PEMBAHASAN}

Tabel 1 Distribusi Karateristik Remaja yang Tinggal di Panti Asuhan di Kota Padang Tahun $201(n=256)$

\begin{tabular}{llcc}
\hline $\begin{array}{c}\text { Karateristik } \\
\text { Remaja }\end{array}$ & \multicolumn{1}{c}{ Kategori } & $\mathrm{f}$ & $\%$ \\
\hline Umur & $<15-18$ Tahun & 191 & 74,6 \\
& 19 -20 Tahun & 65 & 22,4 \\
Jenis & Perempuan & 175 & 68,4 \\
Kelamin & Laki - Laki & 81 & 31,6 \\
\hline
\end{tabular}

Berdasarkan tabel 1 memperlihatkan dari 256 remaja sebagian besar usia anak yang tinggal dipanti asuhan usia 16 - 18. Untuk jenis Kelamin sebagian besar adalah perempuan dimana hampir seluruh anak remaja dipanti asuhan memiliki orang tua baik yatim maupun piatu.

Analisa Univariat
Tabel 2 Distribusi Frekuensi Self Esteem Pada Remaja di Panti Asuhan Kota Padang Tahun $2019(n=256)$

\begin{tabular}{cccc}
\hline Variabel & Kategori & $\mathrm{f}$ & $\%$ \\
\hline Self Esteem & Negatif & 134 & 52,3 \\
& Positif & 122 & 47,7 \\
\hline
\end{tabular}

Berdasarkan tabel proporsi diatas lebih dari setengah $(52,3 \%)$ remaja yang tinggal di panti asuhan memiliki self esteem (harga diri) yang rendah.
Tabel 3 Distribusi Frekuensi Faktor Sosial Pada Remaja di Panti Asuhan Kota Padang Tahun 2019 ( $n=256)$

\begin{tabular}{clcc}
\hline Variabel & Kategori & $\mathrm{f}$ & $\%$ \\
\hline Faktor Sosial & Tinggi & 113 & 44,1 \\
& Rendah & 143 & 55,9 \\
\hline
\end{tabular}

Tabel proporsi diatas menunjukan bahwa lebih dari setengahnya remaja memiliki faktor sosial (lingkungan dan teman sebaya) sangat rendah sebanyak $(55,9 \%)$. 
Tabel 4 Item Analisis Faktor Sosial Remaja Yang Tinggal di Panti Asuhan di Kota Padang Tahun 2019 ( $n=256)$

\begin{tabular}{lcccc}
\hline \multirow{2}{*}{ Pernyataan } & \multicolumn{2}{c}{ Tinggi } & \multicolumn{2}{c}{ Rendah } \\
\cline { 2 - 5 } & $\mathbf{f}$ & $\mathbf{\%}$ & $\mathbf{f}$ & $\%$ \\
\hline Teman mendengarkan keluhan saya & 125 & 48,8 & 131 & 51,2 \\
Teman beri nasehat dan arahan kepada saya & 112 & 43,8 & 144 & 56,3 \\
teman-teman saya menghargai saya & 119 & 46,5 & 137 & 53,5 \\
Teman memberikan perhatian kepada saya & 118 & 46,1 & 138 & 53,9 \\
Teman mengajak saya mengikuti kegiatan & 111 & 43,4 & 145 & 56,6 \\
Teman bersedia meminjamkan barangnya & 112 & 43,8 & 144 & 56,3 \\
meminta pendapat teman dalam menyelesaikan masalah & 116 & 45,3 & 140 & 54,7 \\
Teman-teman sangat membantu saya & 213 & 83,2 & 43 & 16,8 \\
Teman membantu saya memecahkan masalah & 123 & 48,0 & 133 & 52,0 \\
Teman membutuhkan saya dalam persahabatan & 119 & 46,5 & 137 & 53,5 \\
Saya adalah seorang yang ramah & 215 & 84,0 & 41 & 16,0 \\
Saya lebih populer dikalangan perempuan & 127 & 49,6 & 129 & 50,4 \\
Saya lebih populer dikalangan laki-laki & 188 & 73,4 & 68 & 26,6 \\
Saya merasa marah terhadap semua orang & 213 & 83,2 & 43 & 16,8 \\
Saya tidak tertarik apa yang orang lain lakukan & 136 & 53,1 & 120 & 46,9 \\
Saya sulit untuk mengembangkan kedekatan dengan orang lain & 157 & 61,3 & 99 & 38,7 \\
Saya bisa bersosialisasi & 231 & 90,2 & 25 & 9,8 \\
Saya puas dengan cara saya memperlakukan orang lain & 72 & 28,1 & 184 & 71,9 \\
Saya berusaha untuk disenangi & 222 & 86,7 & 34 & 13,3 \\
Saya harus lebih sopan kepada orang lain & 171 & 66,8 & 85 & 33,2 \\
Saya tidak pintar dalam bergaul & 162 & 63,3 & 94 & 36,7 \\
Saya tidak puas dengan cara saya bergaul dengan orang lain & 146 & 57,0 & 110 & 43,0 \\
Saya mencoba Imemahami pandangan orang & 113 & 44,1 & 143 & 55,9 \\
Saya memiliki kesan yang baik pada semua orang yang saya temui & 125 & 48,8 & 131 & 51,2 \\
Saya bisa menjadi teman dengan semua orang & 118 & 46,1 & 138 & 53,9 \\
Saya tidak merasa sulit untuk berbicara dengan orang lain & 129 & 50,4 & 127 & 49,6 \\
Sulit bagi saya untuk mengampuni orang lain & 131 & 51,2 & 125 & 48,8 \\
Saya berbicara dengan seseorang yang saya tidak tahu & 179 & 69,9 & 77 & 30,1 \\
\hline
\end{tabular}

Tabel 4 menunjukan aspek pada faktor sosial lebih dari setengahnya $(71,9 \%)$ item yang paling rendah adalah tidak ada kepuasan dalam memperlakukan orang lain. Aspek faktor sosial remaja yang paling tinggi adalah sebagian besar $(86.7 \%)$ remaja yang tinggal dipanti asuhan memiliki usaha untuk disenangi oleh teman sebaya dan masyarakat sekitar.

\section{Analisa Bivariat}

Berdasarkan hasil penelitian yang telah dilakukan didapatkan dari tabel 5.15 bahwa harga diri (self esteem) sebagian remaja yang tinggal dipanti memiliki self esteem (harga diri) yang rendah dengan $p$ Value $<a(P=0,504)$ maka dapat disimpulkan Berdasarkan uji statistik menggunakan chi-square diketahui bahwa tidak ada hubungan yang bermakna antara faktor Sosial. Hasil Analisis juga diaperoleh nilai odd ratio (OR) sebesar 1,342 yang artinya self esteem pada remaja berpeluang 1 kali lebih besar mengalami faktor sosial. 


\section{Tabel 5 Hubungan Faktor Sosial Dengan Self Esteem (Harga Diri )Pada Remaja Yang Tinggal Di Panti} Asuhan Kota Padang $(n=256)$

\begin{tabular}{|c|c|c|c|c|c|c|c|c|}
\hline \multirow{3}{*}{$\begin{array}{c}\text { Variabel } \\
\text { Faktor Sosial }\end{array}$} & \multicolumn{4}{|c|}{ Self Esteem } & \multirow{2}{*}{\multicolumn{2}{|c|}{ Total }} & \multirow{3}{*}{$\begin{array}{c}P \\
\text { value }\end{array}$} & \multirow{3}{*}{$\begin{array}{c}\text { OR } \\
(95 \% \mathrm{Cl})\end{array}$} \\
\hline & \multicolumn{2}{|c|}{ Negatif } & \multicolumn{2}{|c|}{ Positif } & & & & \\
\hline & $f$ & $\%$ & $f$ & $\%$ & $f$ & $\%$ & & \\
\hline Rendah & 78 & 54,5 & 65 & 45,5 & 143 & 100 & 0,504 & 0,819 \\
\hline Tinggi & 56 & 49.6 & 57 & 50,4 & 113 & 100 & & $(0,499-1,342)$ \\
\hline
\end{tabular}

\section{PEMBAHASAN}

\section{Univariat}

Karakteristik Remaja

Karateristik remaja yang telah dilakukan di Panti asuhan kota Padang, didapatkan proporsi bahwa lebih dari setengahnya $(74.6 \%)$ Remaja berusia 15-18 tahun. Didukung oleh penelitian Gandaputra (2017) panti asuhan di jakarta mengungkapkan bahwa remaja yang tinggal dipanti asuhan berusia 15-18 tahun. Abdolencent (2011) melakukan study pada remaja 13-16 tahun yang tinggal dipanti asuhan Narka Turki memiliki ketidakpuasan terhadap diri dan teman sekolah, kualitas diri yang rendah.

Hal ini dapat terjadi karna pada usia remaja merupakan usia kritis yang akan mencari jati dirinya yang akan dapat mempengaruhi harga diri seorang remaja.Usia remaja adalah masa transisi untuk mulai bertanggung jawab, membuat pilihan terutama dalam melepas nilai-nilai yang lama dan memperoleh nila-nilai yang baru untuk mencapai kedewasaan.Pada usia remaja ini terjadi berbagai perubahan fisik, sosial, psikologis, kognitif serta kemampuan untuk mengekspresikan dan memahami emosi untuk memberikan pengalaman emosional yang mempengaruhi perilaku (Priyanka, Parasar, \& Dewangan, 2018).

Hasil analisis karateristik lainya memperlihatkan proporsi jenis kelamin remaja dalam penelitian ini lebih dari setengahnya $(68,4 \%)$ adalah perempuan.Penelitian ini sejalan dengan Androe (2017) mengungkapkan bahwa remaja yang tinggal di panti asuhan Jakarta adalah perempuan. Perempuan merupakan yang paling cepat terpengaruh dengan gangguan harga diri. Harga diri seorang perempuan lebih cepat terganggu dibandingkan laki-laki (Duraku \& Hoxha, 2018). Webb (2014) mengatakan bahwasanya perempuan remaja cenderung gampang mengalami gangguan harga diri.

Raesandra (2016) anak remaja yang tinggal dipanti asuhan kasmir memiliki konsep harga diri yang lebih rendah dari anak yantim remaja laki-laki dalam domain keluarga, fisik dan konsep harga diri. Hal ini dikarenakan proses pencarian jati diri yang belum matang, memiliki kesadaran citra diri yang rendah sehingga membuat remaja perempuan tidak memiliki harga diri yang baik.

Analisis peneliti mengungkap kan bahwa pada masa ramaja perempuan yang tinggal dipanti asuhan rentan mempengaruhi self esteem (harga Diri) dimana perempuan rentan terhadap agangguan citra dirinya, lebih mudah mengungkapkan hal-hal negatif taentang diri mereka, khawatir tentang kemampuan mereka dibandingkan dengan remaja laki-laki adanya penilaian negatif terhadap dirinya maupun orang lain.

\section{Gambaran Self Esteem (Harga Diri) Remaja}

Gambarann Self Esteem remaja dipanti asuhan dikota padang tahun 2019 menunjukan lebih dari setengah remaja (52,3\%) menagalami Self Esteem (harga diri) rendah. Penelitian ini didukung oleh penelitian Wirausaha (2017) dimana remaja yang tinggal dipanti asuhan lebih banyak memiliki Self esteem rendah $(52,17 \%)$ lebih dari setengahnya remaja. Penelitian Asif (2017) di dapatkan bahwa remaja yang tinggal dipanti asuhan cenderung memiliki harga diri yang lebih rendah dibandingkan dengan remaja yang tidak tinggal di panti asuhan atau yang tinggal bersama orang tua.Resty (2016) bahwa anak remaja yang tinggal dipanti asuhan aisyah yogyakarta lebih dari setengahnya $(65,8 \%)$ memiliki harga diri yang rendah.

Hal ini disebabkan anak yang tinggal dipanti asuhan mengalami banyak problem psikologis dengan karakter sebagai berikut : kepribadian yang inferior, pasif, apatis, menarik diri, mudah putus asa, penuh dengan ketakutan dan kecemasan ini meunjukan tidak terpenuhnya kebuuhan anak panti asuhan secara psikologis maupun sosial seperti layaknya anak-anak lain yang memiliki keluarga.

Berdasarkan analisa kuesioner gejala harga diri negatif rendah pada remaja yang dirasakan adalah bahwa lebih dari setengahnya $(75,8 \%)$ remaja yang tinggal dipanti asuhan merasa 
tidak puas dengan dirinya sendiri membuat dirinya menarik diri dari lingkungan .Hasil analiss ini didukung oleh (Stuart, 2012) menyebutkan bahwa Harga diri merupakan sebuah penilaian yang dilakukan terhadap diri individu dibandingkan dengan pencapaian ideal diri yang telah ditetapkan sebelumnya. Harga diri dapat berasal dari diri sendiri atau dari orang lain, misalnya dalam bentuk pengakuan. Pengakuan dari orang lain akan dapat menaikkan harga diri, begitupun sebaliknya apabila orang lain menarik atau tidak memberikan pengakuan maka harga diri seorang individu akan menurun.

Sedangkan gejala haraga diri yang tidak dirasakan oleh remaja yang tinggal dipanti asuhan dikota padang adalah remaja tidakmerasadiriya tidak berguna dalam hal ini remaja $(53,5 \%)$ lebih dari setengahnya mengalami self esteem positif. Penaeliatian ini sejalan dengan penelitian penelitian Widiarti (2017), remaja se SMP Kota Yogyakarta mempunyai konsep diri positif sebesar $54,2 \%$. Menurut Hurlock (2017), konsep diri adalah cara bagaimana individu menilai diri sendiri, bagaimana penerimaannya terhadap diri sendiri sebagaimana yang dirasakan, diyakini, dilakukan, baik ditinjau dari segi fisik, moral, keluarga, personal dan sosial.

Remaja dengan konsep diri positif bersifat stabil, dapat memahami dan menerima sejumlah fakta yang sangat bermacam-macam tentang dirinya sendiri. Berkaitan dengan pengharapan, remaja dengan konsep diri positif merancang tujuan-tujuannya yang sesuai dan realistis (Kiling, 2015).

Bersadarkan analisid peneliti bawasanya setiap individu tentu tidak memiliki tahadap perkembangan yang sama dalam menghdapi gejala Self Esteem karna pada masa remaja ini merupakan salah satu tahap dimana masa transisi antara masa kanak dengan masa dewasa. Perkembangan remaja tersebut yaitu perkembangan fisik, kognitif, sosial, moral dan harga diri berkembang harus sesuai dengan tumbuh kembangnya.Remaja yang sedang masa pertumbuhan dan perkembangan sangat membutuhkan Self esteem dimana pada masa ini remaja searing sekali mengalami fluktuasi dimana prilaku remaja cenderung berubah- ubah sesuai dengan situasi dan lingkungan (Priyanka, Parasar, \& Dewangan, 2018)

Remaja yang tinggal dipanti asuhan sering memiliki perasaan bahwa dirinya tidak sama seperti yang tinggal dengan keluarga utuh, status ekonomi yang rendah merupakan salah satu faktor yang membuat mereka ditolak oleh lingkungan teman sebaya dan pada akhirnya mereka minder dan tidak berharga. Akibatnya anak remaja tersebut kurang memiliki motivasi untuk belajar, tidak jarang pula anak frustasi dan agresif, dan kemarahan tersebut sering diungkapkan dengan prilaku-prilaku yang tidak simpatik terhadap lingkungan sekitar. Hal ini akan berdampak berdampak pada penerimaan diri remaja yang rendah, kaku dalam berhubungan dengan orang lain, mengalami perkembangan yang tidak baik, tidak berprestasi secra maksimal, kurang berani, tidak percaya diri untuk bersaing dengan orang lain, serta ragu dalam mengambil keputusan.

Mengingat pentingnya Self Esteem (harga diri) pada remaja, berbagai macam pendekatan yang bisa dilakukan untuk menigkatkan harga diri.Pendekatan - pendekatan antara lain : peneriman, kepedulian, dukungan sosial, timbal balik positif, modeling, konseling individual kelompok maupun terapi keluarga, Natural Self Esteem Moment, pendekatan kognitif.

Distribusi Frekuensi Faktor Sosial Remaja Panti Asuhan di Kota Padang

Gambaran faktor sosial remaja yang tinggal dipanti asuhan dikota Padang 2019 mengungkapkan lebih dari setengahnya (55,9\%) bahwa maengalami faktor sosial rendah.Hasil ini didukung oleh (Hartini 2011) anak panti asuhan cenderung mempunyai kepribadian yang inferior, pasif, apatis, menarik diri, mudah putus asaa, penuh dengan ketakutan dan kecemasan sehingga anak pantiasuhan akan sulitmenjalin hubungan sosial dengan orang lain. Andani (2015) mengungkapkan bahwa pada penyesuaian sosial pada remaja yang tinggal dipanti asuhan adanya hambatan baik dari dalam individu (sifat dasar subjek yang pendiam, pemalu, minder dan menutup diri dari alingkungan sosialnya maupun hambatan dari lauar individu (lingkungan panti asuhan, teman sebaya dan lingkungan masyarakat yang tidak mendukung)

Rendahnya dukungan sosial yang didapatkan remaja panti asuhan disertai dengan diskriminasi yang didapatkan menyebabkan timbulnya permasalahan psikologis pada diri remaja, seperti depresi, hilangnya harga diri, dan keengganan untuk berinteraksi dengan lingkungan sosial (Demoze, Angaw, \& Mulat, 2018). Berdasarkan analisis kuesioner bahwa lebih dari setengahnya $(71,9 \%)$ mengungkapkan bahwa remaja tidak puas dengan cara dia memperlakukan orang lain. Remaja cenderung melakukan apapun demi diterima dilingkungan dan temantemannya.Remaja yang tinggal di panti asuhan memiliki lingkungan sosial yang berbeda dengan remaja yang tinggal bersama orang tua(Muhith, 
2015). Remaja akan cenderung minder dan lebih mengurung diri tidak mau bergaul dengan teman sebaya atau masyarakat. Hal ini dapat mempengaruhi perkembangan remaja tersebut (Gürsoy et al, 2012)

Berdasarkan asumsi peneliti jika remaja memiliki tidak puas dengan kemampuan dirinya, tidak memberikan penghargaan terhadap diri sendiri tidak mampu mengekspesikan dirinya didalam lingkungan sosial. Perihal ini akan membuat remaja cenderung pesimis, tidak mampu terhadap kritik, memiliki gejala Self Esteem negatif sehingga merasa menarik diri,merasa tidak nyaman terhadap keberadaannya di dalam lingkungan sosialnya.

\section{Bivariat}

Hubungan Faktor Sosial dengan Harga Diri Remaja yang Tinggal di Panti Asuhan

Kelompok sosial memberikan arahan, pedoman agar seorang individu mengikuti perilaku yang sesuai dengan aturan-aturan yang berlaku dari kelompok tersebut (Muhith, 2015). Manusia makhluk sosial yang selalu hidup berkelompok dan tidak bisa hidup sendiri dan membutuhkan sebuah dukungan.Dukungan sosial adalah pemberian informasi baik secara verbal maupun non verbal, bantuan nyata atau tindakan yang diberikan oleh keakraban sosial atau dapat terjadi karena kehadiran mereka disekitar remaja tersebut (Schemmel, 2018).Berdasarkan hal diatas, dapat dikatakan bahwa lingkungan sosial dapat mempengaruhi kondisi fisik dan psikologis remaja.

Remaja yang tinggal di panti asuhan memiliki lingkungan sosial yang berbeda dengan remaja yang tinggal bersama orang tua (Muhith, 2015). Remaja akan cenderung minder dan lebih mengurung diri tidak mau bergaul dengan teman sebaya atau masyarakat. Hal ini dapat mempengaruhi perkembangan remaja tersebut (Gürsoy et al, 2012). Perilaku mengisolasi diri dan tidak mau untuk berinteraksi dengan lingkungan sosial dapat menjadi lingkaran setan yang memperburuk kondisi psikologis remaja.

Rendahnya dukungan sosial yang didapatkan remaja panti asuhan disertai dengan diskriminasi yang didapatkan menyebabkan timbulnya permasalahan psikologis pada diri remaja, seperti depresi, hilangnya harga diri, dan keengganan untuk berinteraksi dengan lingkungan sosial (Demoze, Angaw, \& Mulat, 2018).

Berdasarkan analisis mengungkapkan bahwa remaja tidak puas dengan cara dia memperlakukan orang lain. Remaja cenderung melakukan apapun demi diterima dilingkungan dan teman-temannya.Remaja yang tinggal di panti asuhan memiliki lingkungan sosial yang berbeda dengan remaja yang tinggal bersama orang tua(Muhith, 2015). Remaja akan cenderung minder dan lebih mengurung diri tidak mau bergaul dengan teman sebaya atau masyarakat. Hal ini dapat mempengaruhi perkembangan remaja tersebut (Gürsoy et al, 2012)

Berdasarkan asumsi peneliti jika seseorang memiliki tidak puas dengan kemampuan dirinya, tidak maaemberikan penghargaan terhadap diri sendiri tidak mampu mengekspesikan dirinya didalam lingkungan sosial. Perihal ini akan membuat remaja cenderung pesimis, tidak mampu terhadap kritik, memiliki gejala Self Esteem negatif sehingga merasa menarik diri,merasa tidak nyaman terhadap keberadaannya di dalam lingkungan sosialnya.

Lingkungan sosial merupakan lingkungan yang lebih banyak dikonsumsi individu pada tahap remaja. Menurut Stuart (2012) dikatakan bahwa lingkungan sosial akan memberikan interaksi kepada remaja, salah satu bentuk hasil dari interaksi yang terjadi adalah sebuah pengakuan. Pengakuan yang diberikan dari lingkungan sosial dapat mempengaruhi harga diri seorang individu (Schemmel, 2018).Lingkungan sosial disekitar remaja dapat membentuk atau mempengaruhi harga diri remaja di panti asuhan yang nantinya dapat berdampak pada pembentukan konsep diri remaja.

\section{KESIMPULAN}

Karateristik remaja lebih dari setengahnya adalah perempuan dengan rentang umur $15-20$ tahun yang tinggal dipanti asuhan di kota Padang. Lebih dari setengahnya memiliki Self Esteem rendah pada remaja yang tinggal dipanti asuhan dikota Padang.Tidak terdapatnya hubungan signifikan antara faktor Sosial dengan Self Esteem (harga Diri) remaja yang tinggal dipanti asuhan dikota Padang.

\section{SARAN}

Dari aspek aplikatif diharapkan menjadi dasar dan bahan pertimbangan menyusun program untuk kesejahteraan para anak yang ada di panti asuhan di kota Padang sehingga dapat meningkatkan pengetahuan masyarakat tentang harga diri remaja di panti asuhan di kota Padang. Dari bidang Keilmuan pihak pendidikan dalam dunia keperawatan hendaknya mengembangkan asuhan keperawatan pada kelompok usia remaja yang lebih terfokus kepada harga diri terutama untuk anakanak panti asuhan. Pihak pendidikan harus mengoptimalkan pemberian asuhan keperawatan 
sesuai dengan perkembangan usia remaja agar mereka dapat paham tentang apa saja tahap perkembangan apa yang akan mereka lalui. Bagi remaja di harapkan kepada remaja agar dapat menilai harga diri sendiri secara dini agar mampu berinteraksi serta bersosialisasi dengan baik di lingkungan baik dilingkungan panti asuhan, sekolah dan masyarakat

\section{DAFTAR PUSKATA}

Badan Pusat Statistik. (2017). Jumlah Panti Asuhan. Jakarta

Badan Pusat Statistik. (2018). Jumlah Remaja di Indonesia. Jakarta.

Bettmann, J. E., Mortensen, J. M., \& Akuoko, K. O. (2015). Orphanage Caregivers' Perceptions of Children's Emotional Needs. Children and Youth Services Review, 49, 71-79. https://doi.org/10.1016/j.childyouth.2015.01 .003

Bharathi, T. A., \& Sreedevi, P. (2013). A Study on the Self-Concept of Adolescents. International Journal of Science and Research (IJSR), 14(10), 2319-7064.

Gürsoy, F., Biçakçi, M. Y., Orhan, E., Bakırcı, S., Çatak, S., \& Yerebakan, Ö. (2012). Study on Self-Concept Levels of Adolescents in the Age Group of 13-18 Who Live in Orphanage and Those Who do not Live in Orphanage. International Journal of Social Sciences and Education, 2(1), 2223-4934. Diambil dari http://www.ijsse.com/sites/default/files/issu es/2012/volume 2 issue 1 Jan 2012/paper 5/paper-05.pdf

Kraja, P. (2014). Self-Concept and Self-Evaluation in the Transition From Primary To Lower Secondary Education. The Eurasia Proceedings of Educational \& Social Sciences, 1(2), 420-426.

Llapo, O. P. (2015). Caregivers Perception of Emotional and Behavioural Difficulties Experienced by Teenage Orphans Living in
Mogapi (Botswana). University of The Witwatersrand.

Muhith, A. (2015). Pendidikan Keperawatan Jiwa. In Teori dan Aplikasi Keperawatan Jiwa.

Nurliana, Y. (2017). Konsep Diri Remaja. psikologi \& kemanusian, 4(2), 978-979.

Nursalam. (2013). Konsep Penerapan Metode Penelitian IImu Keperawatan. Jakarta: Salemba Medika.

Parasar, A., \& Dewangan, R. L. (2018). A Comparative Study of Self Esteem and Level of Depression in Adolescents Living in Orphanage Home and Those Living With Parents. International Journal of Humanities and Social Science Research, 4(2), 51-53.

Preckel, F., Niepel, C., Schneider, M., \& Brunner, M. (2013). Self-concept in adolescence: A longitudinal study on reciprocal effects of self-perceptions in academic and social domains. Journal of Adolescence, 36(6), 1165-1175. https://doi.org/10.1016/j.adolescence.2013. 09.001

Schemmel, C. (2018). Real self-respect and its social bases. Canadian Journal of Philosophy, 5091, 1-24. https://doi.org/10.1080/00455091.2018.146 3840

Stuart, G. W. (2012). Principles and Practice of Psyhchiatric Nursing. Missouri: Elsevier Ltd.

Syawaluddin. (2015). Konsep Diri Anak Ditinjau Dari Jenis Kelamin di Panti Asuhan Kota Padang. Journal of Gender Studies, 1(1), 75-86. Diambil dari http://www.ejournal.iainbukittinggi.ac.id

World Health Organization. (2015). Pengelompokan Usia. New York.

World Health Organization. (2017). Health Adolescence 2017. New York.

World Health Organization. (2018). Health Adolescence 2017. New York. 